\title{
Ketamine Reduces the Cell Death Following Inflammatory Pain in Newborn Rat Brain
}

\author{
KANWALJEET J.S. ANAND, SARITA GARG, CYNTHIA R. ROVNAGHI, UMESH NARSINGHANI, ADNAN T. BHUTTA, \\ AND RICHARD W. HALL \\ Pain Neurobiology Lab, Arkansas Children's Hospital Research Institute, Little Rock, Arkansas 72202; Department of Pediatrics, \\ University of Arkansas for Medical Sciences, College of Medicine, Little Rock, Arkansas 72205
}

\begin{abstract}
Premature infants experience untreated repetitive pain that may alter their brain development. Effects of ketamine and repetitive pain on cellular death and subsequent behavior were studied in neonatal rats. Rat pups were randomized to undisturbed controls (C), 4\% formalin injection $(\mathrm{F})$, ketamine alone $(\mathrm{K}, 5 \mathrm{mg} / \mathrm{kg})$ or formalin plus ketamine $(\mathrm{KF})$ and were assessed for neuroactivation with Fos protein, cellular death with FluoroJade-B, cognition with the radial arm maze, and pain thresholds with the hot-plate. Greater Fos expression and cell death occurred in F vs. C groups in defined brain areas at 1 and $4 \mathrm{~h}$ in F compared with other groups. Cell death was accentuated 3.3-fold in cortical areas and 1.6-fold in subcortical areas in the F compared with the $\mathrm{C}$ group following repetitive pain and sacrifice $18-20 \mathrm{~h}$ later. These effects were ameliorated by ketamine. Compared with the F group, all other groups demonstrated greater exploratory and rearing behaviors and decreased time for bait consumption at 1-h and 3-h intervals. Significantly greater thermal pain latencies occurred in the KF and $\mathrm{F}$ groups. Repetitive neonatal pain accentuates neuronal excitation and cell death in developmentally regulated cortical and subcortical areas, which decreases the acquisition of visual-spatial clues, short-term and long-term memory, and increases pain latencies. Ketamine analgesia mitigates most of these effects. (Pediatr Res 62: 283-290, 2007)
\end{abstract}

$\mathrm{C}$ inical studies indicate that exposure to adverse experiences in early life alters brain function and behavior in childhood (1), perhaps related to neuroplasticity of the developing nervous system. Adverse experiences during early development alter neuronal activity patterns and may permanently alter the functional wiring of immature neurons. Epidemiologic associations occur relating perinatal or neonatal complications with behavioral and emotional problems in childhood (2), altered pain responses $(1,3,4)$, anxiety, depression $(2,5)$, or suicidal tendencies $(6,7)$.

Preterm infants experience repetitive pain during critical periods of brain development (8), concurrent with rapid brain growth, exuberant synaptogenesis, increased expression of excitatory receptors (9), and developmentally regulated neuronal cell death (10). Repetitive neonatal pain persistently alters pain processing, in rats $(11)$, mice $(12)$, and humans $(3,4)$, and glucocorticoid responses in older infants (13). Conversely, prolonged treatment

Received January 4, 2007; accepted April 6, 2007.

Correspondence: Kanwaljeet J.S. Anand, D.Phil., Arkansas Children's Hospital, Slot 900, 800 Marshall Street, Little Rock, AR 72202; e-mail: anandsunny@uams.edu

Supported by grants from the National Institute of Child Health and Human Development (HD01123, HD50009), the National Center for Research Resources (RR018765, RR016460), Blowitz-Ridgeway Foundation, UAMS Medical Research Endowment Fund, and Arkansas Children's Hospital Foundation. of infant rats with high doses of analgesic or anesthetic agents triggers widespread neurodegeneration in their brain (14). This vulnerability coincides with the developmental growth spurt in the brain, occurring postnatally in rodents, prenatally in full-term and postnatally in preterm neonates (15). Thus, neuronal activity in the neonatal brain may be required for cell survival and factors that regulate neuronal activity or cell death would play important roles in brain development. This study examines whether repetitive neonatal pain alters neuronal activation or cell death and if these cellular changes are associated cognitive or behavioral sequelae.

\section{METHODS}

All experiments were consistent with National Institutes of Health animal use guidelines and approved by the Animal Care and Use Committee. Timedpregnant Long-Evans hooded rats were moved into cages with increased bedding (3-in layer) in a noise-free parturition room on embryonic (E) day 18 (E18). Pregnant females were handled daily by personnel who provided the animal husbandry. Birthing cages were not changed after nesting occurred and the litters were left undisturbed. Environmental noise, changes in temperature or humidity, or changes in husbandry staff were strictly controlled, maintaining a 12:12-h light-dark cycle, with food and water ad lib. On the day of birth (P0), rat pups were randomly cross-fostered and culled to eight pups per dam.

Single inflammatory pain. Rat pups were randomly assigned to experimental groups killed at $1 \mathrm{~h}$ or $4 \mathrm{~h}$ after $4 \%$ formalin injections into the right forepaw on postnatal day $1(\mathrm{P} 1, n=11), \mathrm{P} 7(n=10), \mathrm{P} 14(n=10)$, or control groups that remained undisturbed until sacrifice on $\mathrm{P} 1(n=10), \mathrm{P} 7(n=6)$, or P14 $(n=6)$.

Repetitive inflammatory pain. Rat pups were randomly assigned to undisturbed controls (C, $n=15$ ), or receiving subcutaneous injections of $4 \%$ formalin $(\mathrm{F}, n=11)$, ketamine alone $(\mathrm{K}, n=12)$, or ketamine and formalin $(\mathrm{KF}, n=10)$. Formalin $(5 \mu \mathrm{L})$ was injected at hourly intervals into each paw once daily from P1 to P4; ketamine $(2.5 \mathrm{mg} / \mathrm{kg} \times 2)$ was injected under the interscapular skin, 5 min before the first and third formalin injections. All rats were killed on P5 to harvest brain tissues at the peak period of neuronal cell death, 18-20 h after the last injection (16).

Cellular staining. Infant rats from all groups were anesthetized with ether and perfused with freshly made, ice-cold $4 \%$ paraformaldehyde. Brains were harvested, immersed in paraformaldehyde, then $20 \%$ sucrose, and frozen in cryoprotectant. Cryostat (Leica-3050, Wetzler, Germany) sections (20 $\mu \mathrm{m}$ thick) were mounted on positively charged slides and stained with Fos antibody (Oncogene, San Diego, CA) or FluoroJade-B (FJB) (Histo-Chem, Jefferson, AR). FJB staining, a marker for neurodegeneration, and Fos immunohistochemistry were conducted as reported previously $(11,17)$. Two observers, blinded to study group assignment, counted the stain-positive cells in the cortex, hippocampus, amygdala, thalamus, hypothalamus, and habenula. All cell counts were repeated for differences $>8 \%$ and statistical analyses included ANOVA, followed by Dunn's or Tukey-Kramer post hoc tests, with significance set at $p<0.01$.

Radial arm maze test. Visual-spatial learning and memory were measured using standard procedures for the radial 8-arm maze (RAM) in adult rats (18). Before testing, neonatally treated adult rats $(\mathrm{C}=27, \mathrm{~K}=24, \mathrm{KF}=21, \mathrm{~F}=$ 20) were diet-restricted to $85 \%$ of baseline body weight and received training for $5 \mathrm{~d}$ (19). A delayed nonmatch to sample (DNMS) paradigm was used with initial exposure to the radial maze (4 lanes open) followed by a second 
exposure (all 8 lanes open) after intervals of 1 h (on P63) or 3 h (on P64). Within the time required to consume all bait, we measured the frequency and duration of behaviors, including rearing, re-entry into bait eaten arm, time required to eat bait, and incomplete consumption of bait. Data analysis used factorial ANOVA, with significance levels at $p<0.05$.

Hot-plate test. Hot plate (HP) testing for thermal pain thresholds was performed using an analgesiometer (Omnitech, Dartmouth, NS, Canada) as described previously $(11,20)$. Pain thresholds were measured by the latency to limb shaking or paw lick with a maximum exposure time of $30 \mathrm{~s}$. HP latency was averaged from three trials with 15 -min intervals between each trial.

\section{RESULTS}

\section{Single Inflammatory Pain}

Bilateral expression of fos protein occurs following formalin injection. Bilateral increases in Fos protein expression occurred following unilateral inflammation in the right fore- paw in P1, P7, and P14 rat pups, mostly limited to the amygdala, hypothalamus, thalamus, and piriform cortex. Compared with age-matched controls, P1 rats showed transient Fos expression in the amygdala and piriform cortex; P7 rats showed transient increases in the amygdala and thalamus (Fig. $1 A$ and $B$ ). Fos expression at P14 was developmentally distinct from P1 and P7, with prolonged increases in the amygdala, hypothalamus, hippocampus, and multiple cortical areas (including somatosensory cortex) compared with controls.

Neuronal cell death following inflammatory pain is developmentally regulated. Compared with age-matched control rats, cell death at P1 occurred bilaterally in the cortical, thalamic, hypothalamic, amygdaloid, and hippocampal areas.
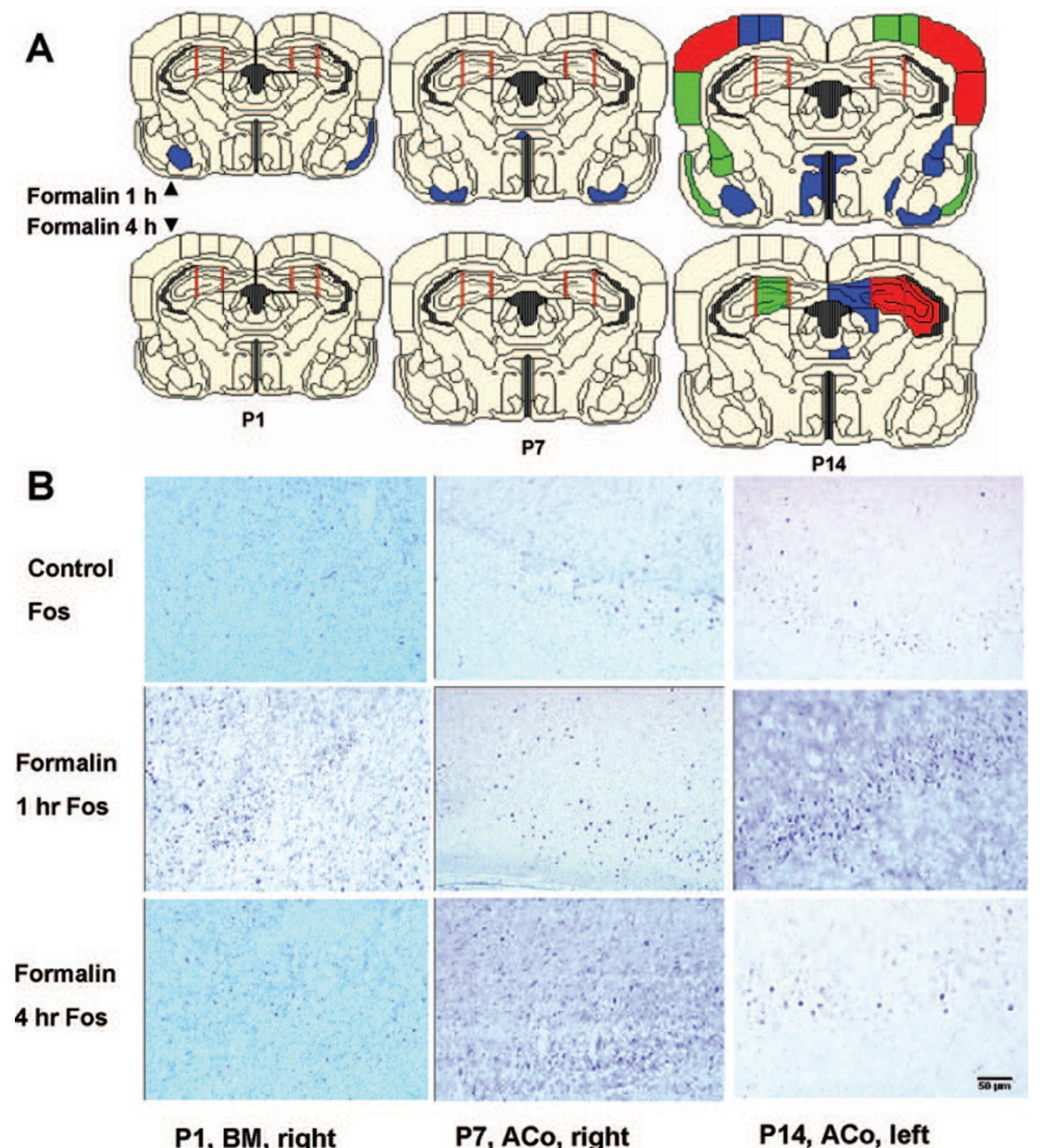

Figure 1. (A) Neuronal Fos expression differences (blue $p<0.05$, green $p<0.01$, red $p<0.001$ ) between control groups (P1: $n=10$, P7: $n=6$, P14: $n=$ 6) and those at $1 \mathrm{~h}$ and $4 \mathrm{~h}$ after formalin injection (P1: $n=11, \mathrm{P} 7: n=10, \mathrm{P} 14: n=10)$. P1 rats: Fos expression increased at $1 \mathrm{~h}$ in the ipsilateral basomedial amygdaloid nucleus and contralateral piriform cortex; no differences occurred at $4 \mathrm{~h} . P 7$ rats: Fos expression increased at $1 \mathrm{~h}$ in the cortical amygdaloid nuclei bilaterally and ipsilateral reuniens thalami, with no differences at 4 h. P14 rats: At 1 h, Fos expression increased bilaterally in lateral/basolateral amygdaloid nuclei, parietal cortex areas 1 and 2, frontal and piriform cortex; hypothalamic paraventricular and periventricular nuclei. Fos expression increased ipsilaterally in the basomedial amygdaloid nucleus, anterior hypothalamic nucleus; contralaterally in the cortical amygdaloid and medial amygdaloid nuclei. At $4 \mathrm{~h}$, hippocampal, anterodorsal and central medial thalamic nuclei showed greater Fos expression. $(B)$ Photomicrographs $($ scale bar $=50 \mu \mathrm{m})$ from selected nuclei at P1 (basomedial amygdaloid), P7 (cortical amygdaloid), and P14 (cortical amygdaloid), showing Fos expression at $1 \mathrm{~h}$ and $4 \mathrm{~h}$ after formalin injection. 


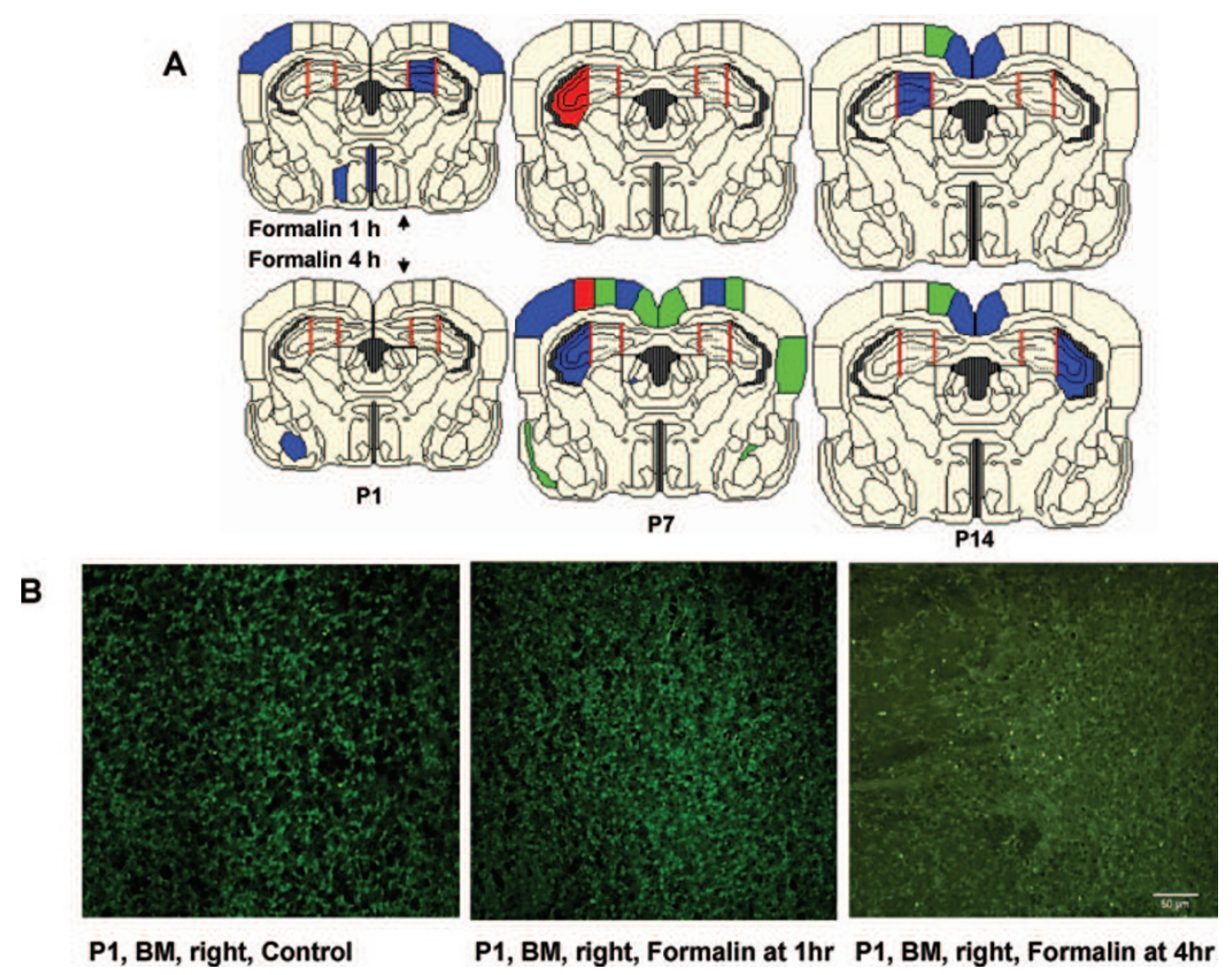

Figure 2. (A) Pictograms of differences in cell death from control group, at $1 \mathrm{~h}$ and $4 \mathrm{~h}$ following $4 \%$ formalin injection (blue $p<0.05$, green $p<0.01$, red $p<0.001$ ). P1 rats: Cell death increased bilaterally at $1 \mathrm{~h}$ in the parietal cortex (area 1), contralateral hippocampus, lateral and periventricular hypothalamic nuclei. Greater cell death at $4 \mathrm{~h}$ following $4 \%$ formalin injection occurred in the ipsilateral basomedial amygdaloid nucleus (also illustrated in the photomicrographs magnified 20-fold). P7 rats: Neuronal cell death increased following 4\% formalin injection in the ipsilateral hippocampus at $1 \mathrm{~h}$. At $4 \mathrm{~h}$, cell death increased bilaterally in the frontal, hind limb, and granular retrosplenial cortex; ipsilaterally in parietal cortex (area 1), agranular retrosplenial cortex, piriform cortex, lateral habenula and lateral hippocampus; and contralaterally in intercalated amygdaloid and parietal cortex (area 2). P14 rats: Neuronal cell death increased at $1 \mathrm{~h}$ only in the retrosplenial cortex (granular, agranular) and ipsilateral hippocampus, but occurred at $4 \mathrm{~h}$ bilaterally in the retrosplenial cortex and the contralateral hippocampus. $(B)$ Photomicrographs (scale bar $=50 \mu \mathrm{m}$ ) from basomedial amygdaloid nuclei in P1 rats, showing greater cell death at $1 \mathrm{~h}$ and $4 \mathrm{~h}$ after formalin injection.

Widespread cell death also occurred in P7 rats, bilaterally affecting multiple cortical areas and unilaterally the hippocampus, amygdala, habenular, and hypothalamic nuclei. Minimal cell death occurred at P14, only localized to the retrosplenial cortex and the hippocampus (Figure. 2).

\section{Repetitive Inflammatory Pain}

Ketamine blocks the cell death following repeated formalin injections. Compared with controls (C group), cell death in the $\mathrm{F}$ group following repetitive pain from $\mathrm{P} 1$ to $\mathrm{P} 4$ was accentuated 3.3-fold in cortical areas and 1.6-fold in subcortical areas. These effects were ameliorated in the ketaminetreated groups (KF or K) (Fig. 3A). Minimal or no differences occurred in the thalamic nuclei or habenula, suggestive of low NMDA receptor activity (21). Post hoc analyses showed that cell death increased significantly in the $\mathrm{F}$ group, with no differences between the $\mathrm{C}, \mathrm{KF}$, and $\mathrm{K}$ groups.

Reduced fos expression occurs following repetitive pain. Fos expression at $18 \mathrm{~h}$ after the last injection serves as a marker for neuronal viability and environmental inputs, rather than pain-induced activation (11). Significant differences occurred in the habenula, hippocampus, amygdala and thalamus, but not in the hypothalamus (Fig. 3B). Fos expression patterns between randomized groups showed post hoc differences as: $\mathrm{C}=\mathrm{KF}>\mathrm{K}>\mathrm{F}$.

Ketamine reduces neuronal cell death in anatomically defined areas. Adjacent sections stained for cell death and Fos expression showed significant group differences within anatomically defined cortical and subcortical areas (Table 1). Most of the differences occurred between the $\mathrm{C}$ and $\mathrm{F}$ groups, with increased cell death in cortical, hippocampal, and other subcortical areas and reduced Fos expression in the limbic, thalamic, and hypothalamic areas (Fig. 4 and Table 1). No differences in cell death occurred between the $\mathrm{C}$ and $\mathrm{KF}$ groups, whereas the $\mathrm{K}$ group showed reduced cell death and reduced Fos expression in isolated thalamic and amygdalar nuclei (Fig. 4).

Impaired visual-spatial cues occur in adult rats neonatally exposed to repetitive pain. Short-term memory tested at 1-h intervals showed lower frequencies of rearing or arm entries in the F group (Fig. $5 A$ and $B$ ), with reduced time for exploratory behaviors (Fig. $5 \mathrm{C}$ ). Exploratory and rearing behaviors increased in the ketamine-treated groups $(\mathrm{K}, \mathrm{KF})$, implying greater acquisition of visual-spatial cues. Following 3-h intervals for testing long-term memory, the $\mathrm{F}$ group required longer times for bait consumption (Fig. 5D). This, with a 

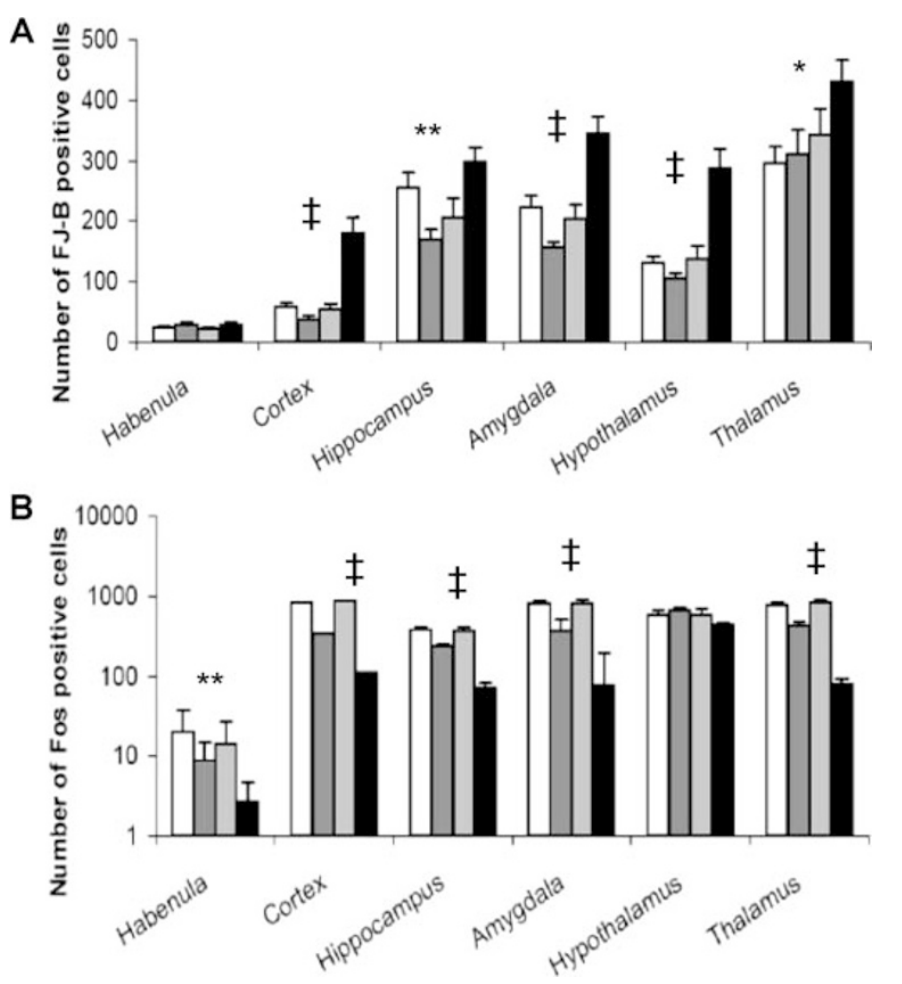

Figure 3. (A) Neuronal cell death was significantly different between groups in the cortex, hippocampus, amygdala, hypothalamus, and thalamus, but not in the habenula. Cell death was significantly increased in the cortex, amygdala, and hypothalamus $(p<0.001)$ in the formalin (F, black, $n=11)$ group compared with all other groups [controls (C, white, $n=15)$, ketamine (K, dark grey, $n=12$ ), and ketamine-formalin (KF, light gray, $n=10)]$. In the hippocampus, greater cell death occurred in the $\mathrm{F}$ group compared with the $\mathrm{K}$ group $(p<0.01)$; in the thalamus, greater cell death occurred in the F group compared with the $\mathrm{C}$ group $(p<0.05)$. No differences in cell death occurred between the $\mathrm{C}, \mathrm{K}$, or KF groups in any brain region. (B) Significant group differences occurred for neuronal Fos expression in cortex, hippocampus, amygdala, thalamus, and habenula, but not hypothalamus. Post hoc analyses showed no differences in Fos expression between $\mathrm{C}$ and KF groups. F group showed lower Fos expression in the cortex, hippocampus, amygdala, thalamus (all $p<0.001$ ) and habenula $(p<0.01)$, whereas the $\mathrm{K}$ group showed lower Fos expression in the cortex, amygdala, thalamus (all $p<0.001$ ), and hippocampus $(p<0.01)$, compared with the $\mathrm{C}$ and KF groups. Greater Fos expression occurred in the $\mathrm{K} v s$. F groups, in the hippocampus $(p<0.01)$, amygdala $(p<0.05)$ and thalamus $(p<0.001) .\left({ }^{*} p<0.05\right.$; $* * p<0.01$; $\ddagger p<0.001)$.

higher incidence of uneaten bait, implies impaired learning in a DNMS paradigm.

Ketamine treatment ameliorates pain threshold changes in adult females but not in males. Thermal pain latencies were significantly reduced in the $\mathrm{C}$ and $\mathrm{K}$ groups compared with $\mathrm{F}$ and $\mathrm{KF}$ groups, confirming long-term effects of neonatal inflammatory pain (20). Ketamine appeared to ameliorate these long-term effects in adult females, but not in males (Fig. 6).

\section{DISCUSSION}

Exposure to repetitive or prolonged pain occurs during critical periods of brain development in preterm neonates $(8,22)$, which may alter the structure and function of their developing brains $(23,24)$. Brief inflammatory pain in the right forepaw led to bilateral increases in neuronal activation, with a shift from subcortical to cortical processing between P7 and P14, and to increased cell death occurring more prominently at $\mathrm{P} 1$ and $\mathrm{P} 7$ than at P14. Repetitive inflammatory pain from P1 to P4 accentuated cell death 3.3-fold in cortical areas and 1.6-fold in subcortical areas; these effects were blocked by analgesic doses of ketamine $(5 \mathrm{mg} / \mathrm{kg})$. Increased cell death in multiple cortical and limbic areas, may reduce neuronal viability and activation in widespread subcortical areas. These effects were largely blocked in rat pups given ketamine analgesia, suggesting a neuroprotective role in newborn rats exposed to repetitive inflammatory pain. Diminished cognitive function and higher pain thresholds occurred in adult rats following neonatal inflammatory pain, but only the cognitive effects were ameliorated by ketamine analgesia.

Multiple follow-up studies of ex-preterm children have reported developmental deficits $(25,26)$, with greater needs for special education (27) and health care (28). Repetitive pain or maternal separation, both occurring routinely in preterm babies, may lead to abnormal pain processing, increased anxiety/stress disorders, attention deficit disorder, cognitive and behavioral sequelae $(2,26,29,30)$. Rats exposed to repetitive neonatal pain also develop increased anxiety, hypervigilance, and exaggerated startle responses (11), possibly mimicking some of the behaviors of expreterm children $(2,26,29,30)$.

Preterm neonates are exposed to acute and inflammatory pain from frequent heelsticks, localized infections, indwelling catheters and drains, postsurgical infections, venipunctures, extravasation or phlebitis, or chemical or thermal burns. The frequency and duration of these stimuli cannot be replicated in animal models because of ethical constraints; therefore, we developed a model using short-term inflammatory pain. We chose $4 \%$ formalin injected subcutaneously, producing inflammation for 3-4 $\mathrm{h}$, rather than prolonged inflammation caused by carrageenan or CFA (which also leads to chronic autoimmune arthritis in adult rats). Further, the formalin test has been well-studied in newborn rats $(31,32)$, but with limited data on its long-term effects (20). The biphasic response to formalin in adult rats, occurs as a uniphasic pattern lasting $2-4 \mathrm{~h}$ in neonatal rats (33). Since each paw was injected only once a day, little or no inflammation remained when subsequent injections were given.

Significant age-dependent patterns occurred in neuronal Fos expression, with bilateral activation following unilateral pain, consistent with cortical activation in human preterm neonates (23). Neuronal activation at P1 and P7 was distinct from that at P14 (Fig. 1), with limbic system activation at the earlier ages, extending to the cortical, hippocampal, and hypothalamic areas by P14. Fos expression patterns were mostly transient (occurring at $1 \mathrm{~h}$, but not at $4 \mathrm{~h}$ ), confirming the limited duration of formalin-induced pain (33) compared with other models (34). Unilateral injection was also associated with bilateral cell death, accentuated in the younger rats ( $\mathrm{P} 1$, $\mathrm{P} 7)$, primarily affecting subcortical areas in P1 rats and cortical areas in $\mathrm{P} 7$ rats (35).

Our repetitive pain paradigm, designed to examine the most vulnerable period of rat brain development, showed markedly 
Table 1. Cellular staining in brain regions and nuclei (sum of cell counts from anterior, intermediate, and posterior sections from P5 rat brains)

\begin{tabular}{|c|c|c|c|c|c|}
\hline \multirow{2}{*}{$\begin{array}{l}\text { Brain regions } \\
\text { and subregions }\end{array}$} & \multirow{2}{*}{$\begin{array}{l}\text { Labels for brain subregions } \\
\text { (also apply to Figures } 1,2,4 \text { ) }\end{array}$} & \multicolumn{2}{|c|}{$\begin{array}{l}\text { Neuronal cell death } \\
\text { (FJB staining) }\end{array}$} & \multicolumn{2}{|c|}{$\begin{array}{l}\text { Neuronal activation } \\
\text { (Fos expression) }\end{array}$} \\
\hline & & K-W ANOVA & Dunn's test & K-W ANOVA & Dunn's test \\
\hline \multicolumn{6}{|l|}{ Habenula: } \\
\hline $\mathrm{LHbL}$ & Lateral habenular nucleus, lateral & NS & & & $\mathrm{C} v s \mathrm{~F}, p<0.01$ \\
\hline LHbM & Lateral habenular nucleus, medial & NS & & $p=0.043$ & $\mathrm{C} v s \mathrm{~F}, p<0.05$ \\
\hline $\mathrm{MHb}$ & Medial habenular nucleus & NS & & $p=0.001$ & $\mathrm{C} v s \mathrm{~F}, p<0.01$ \\
\hline \multicolumn{6}{|l|}{ Cortex: } \\
\hline $\mathrm{Fr}$ & Frontal cortex & $p=0.0018$ & $\mathrm{C} v s \mathrm{~F}, p<0.05$ & NS & \\
\hline HL & Hind limb area of the cortex & $p<0.0001$ & $\mathrm{C} v s \mathrm{~F}, p<0.001$ & NS & \\
\hline $\mathrm{Oc}$ & Occipital cortex & $p=0.0072$ & $\mathrm{C}$ vs $\mathrm{F}, \mathrm{NS}$ & NS & \\
\hline Te1 & Temporal cortex, area 1 & $p<0.0001$ & $\mathrm{C} v s \mathrm{~F}, \mathrm{NS}$ & NS & \\
\hline Te3 & Temporal cortex, area 3 & $p<0.0001$ & $\mathrm{C} v s \mathrm{~F}, \mathrm{NS}$ & NS & \\
\hline Den & Dorsal endopiriform nucleus & $p=0.0188$ & $\mathrm{C} v s \mathrm{~F}, \mathrm{NS}$ & $p<0.0001$ & $\mathrm{C} v s \mathrm{~F}, p<0.001$ \\
\hline Pir & Piriform cortex & $p<0.0001$ & $\mathrm{C} v s \mathrm{~F}, \mathrm{NS}$ & $p<0.0001$ & $\mathrm{C} v s \mathrm{~F}, p<0.001$ \\
\hline RSA & Retrosplenial agranular cortex & $p=0.0015$ & $\mathrm{C} v s \mathrm{~F}, p<0.05$ & $p=0.0016$ & $\mathrm{C} v s \mathrm{~F}, \mathrm{NS}$ \\
\hline RSG & Retrosplenial granular cortex & $p<0.0001$ & $\mathrm{C} v s \mathrm{~F}, p<0.05$ & $p<0.0001$ & $\mathrm{C} v s \mathrm{~F}, p<0.001$ \\
\hline Par1 & Parietal cortex, area 1 & $p<0.0001$ & $\mathrm{C} v s \mathrm{~F}, p<0.05$ & NS & \\
\hline Par2 & Parietal cortex, area 2 & $p<0.0001$ & $\mathrm{C}$ vs $\mathrm{F}, p<0.001$ & $p=0.0166$ & $\mathrm{C} v s \mathrm{~F}, \mathrm{NS}$ \\
\hline \multicolumn{6}{|l|}{ Amygdala: } \\
\hline $\mathrm{AAD}$ & Anterior amygdaloid area, dorsal & $p=0.0003$ & $\mathrm{C} v s \mathrm{~F}, p<0.01$ & $p<0.0001$ & $\mathrm{C} v s \mathrm{~F}, p<0.001$ \\
\hline AAV & Anterior amygdaloid area, ventral & $p=0.0004$ & $\mathrm{C} v s \mathrm{~F}, \mathrm{NS}$ & $p=0.0001$ & $\mathrm{C} v s \mathrm{~F}, p<0.001$ \\
\hline $\mathrm{ACo}$ & Anterior cortical amygdaloid nucleus & $p<0.0001$ & $\mathrm{C} v s \mathrm{~F}, p<0.001$ & $p<0.0001$ & $\mathrm{C} v s \mathrm{~F}, p<0.001$ \\
\hline AStr & Amygdalostriatal transition area & $p=0.0002$ & $\mathrm{C} v s \mathrm{~F}, p<0.01$ & $p=0.0388$ & $\mathrm{C} v s \mathrm{~F}, \mathrm{NS}$ \\
\hline $\mathrm{BL}$ & Basolateral amygdaloid nucleus & NS & & $p=0.0002$ & $\mathrm{C} v s \mathrm{~F}, p<0.001$ \\
\hline $\mathrm{BM}$ & Basomedial amygdaloid nucleus & $p<0.0001$ & $\mathrm{C} v s \mathrm{~F}, \mathrm{NS}$ & $p=0.0134$ & $\mathrm{C} v s \mathrm{~F}, p<0.01$ \\
\hline BMA & $\begin{array}{l}\text { Basomedial amygdaloid nucleus, anterior } \\
\text { part }\end{array}$ & $p=0.0003$ & $\mathrm{C} v s \mathrm{~F}, p<0.05$ & $p<0.0001$ & $\mathrm{C} v s \mathrm{~F}, p<0.001$ \\
\hline BSTIA & Bed nucleus of the stria terminalis & NS & & $p=0.0001$ & $\mathrm{C} v s \mathrm{~F}, p<0.001$ \\
\hline $\mathrm{Ce}$ & Central amygdaloid nucleus & $p=0.0002$ & $\mathrm{C} v s \mathrm{~F}, \mathrm{NS}$ & $p=0.0008$ & $\mathrm{C} v s \mathrm{~F}, p<0.05$ \\
\hline $\mathrm{IM}$ & Intercalated nuclei of the amygdala & NS & & $p<0.0001$ & $\mathrm{C} v s \mathrm{~F}, p<0.001$ \\
\hline $\mathrm{La} / \mathrm{BL}$ & Lateral amygdaloid nucleus & $p=0.0004$ & $\mathrm{C}$ vs $\mathrm{F}, \mathrm{NS}$ & $p<0.0001$ & $\mathrm{C} v s \mathrm{~F}, p<0.001$ \\
\hline $\mathrm{Me}$ & Medial amygdaloid nucleus & $p=0.0035$ & $\mathrm{C}$ vs $\mathrm{F}, \mathrm{NS}$ & $p=0.0065$ & $\mathrm{C} v s \mathrm{~F}, p<0.01$ \\
\hline MeAV & $\begin{array}{l}\text { Medial amygdaloid nucleus, anteroventral } \\
\text { part }\end{array}$ & $p<0.0001$ & $\mathrm{C} v s \mathrm{~F}, p<0.001$ & $p<0.0001$ & $\mathrm{C} v s \mathrm{~F}, p<0.001$ \\
\hline MePV & $\begin{array}{l}\text { Medial amygdaloid nucleus, } \\
\text { posteroventral part }\end{array}$ & $p<0.0001$ & $\mathrm{C} v s \mathrm{~F}, p<0.05$ & $p<0.0001$ & $\mathrm{C} v s \mathrm{~F}, p<0.001$ \\
\hline PLCo & $\begin{array}{l}\text { Posterolateral cortical amygdaloid } \\
\text { nucleus }\end{array}$ & $p=0.0002$ & $\mathrm{C} v s \mathrm{~F}, p<0.05$ & $p<0.0001$ & $\mathrm{C} v s \mathrm{~F}, p<0.001$ \\
\hline $\mathrm{PMCo}$ & $\begin{array}{l}\text { Posteromedial cortical amygdaloid } \\
\text { nucleus }\end{array}$ & $p=0.0002$ & $\mathrm{C} v s \mathrm{~F}, p<0.05$ & $p<0.0001$ & $\mathrm{C} v s \mathrm{~F}, p<0.001$ \\
\hline St & Stria terminalis & $p=0.0005$ & $\mathrm{C} v s \mathrm{~F}, \mathrm{NS}$ & NS & \\
\hline \multicolumn{6}{|l|}{ Hippocampus: } \\
\hline DG & Hippocampus, dentate gyrus & $p=0.0078$ & $\mathrm{C}$ vs $\mathrm{F}, \mathrm{NS}$ & $p<0.0001$ & $\mathrm{C} v s \mathrm{~F}, p<0.001$ \\
\hline CA1 & Area CA1 & $p=0.0043$ & $\mathrm{C} v s \mathrm{~F}, \mathrm{NS}$ & $p<0.0001$ & $\mathrm{C} v s \mathrm{~F}, p<0.001$ \\
\hline CA3 & Area CA3 & $p=0.0035$ & $\mathrm{C} v s \mathrm{~F}, \mathrm{NS}$ & $p<0.0001$ & $\mathrm{C} v s \mathrm{~F}, p<0.001$ \\
\hline \multicolumn{6}{|l|}{ Hypothalamus: } \\
\hline $\mathrm{AH}$ & Anterior hypothalamic nucleus & $p<0.0001$ & $\mathrm{C} v s \mathrm{~F}, p<0.01$ & $p=0.0149$ & $\mathrm{C} v s \mathrm{~F}, p<0.05$ \\
\hline AHP & Anterior hypothalamic area, posterior & $p=0.0010$ & $\mathrm{C}$ vs $\mathrm{F}, \mathrm{NS}$ & $p=0.0234$ & $\mathrm{C} v s \mathrm{~F}, \mathrm{NS}$ \\
\hline Arc & Arcuate hypothalamic nucleus & $p<0.0001$ & $\mathrm{C} v s \mathrm{~F}, p<0.001$ & NS & \\
\hline $\mathrm{LH}$ & Lateral hypothalamic area & $p<0.0001$ & $\mathrm{C} v s \mathrm{~F}, \mathrm{NS}$ & $p=0.0246$ & $\mathrm{C} v s \mathrm{~F}, p<0.05$ \\
\hline LH/MTu & Medial tubular nucleus & NS & & $p=0.0104$ & $\mathrm{C} v s \mathrm{~F}, \mathrm{NS}$ \\
\hline $\mathrm{Pa}$ & Paraventricular hypothalamic nucleus & $p=0.0006$ & $\mathrm{C} v s \mathrm{~F}, p<0.01$ & $p=0.0002$ & $\mathrm{C} v s \mathrm{~F}, p<0.01$ \\
\hline $\mathrm{Pe}$ & Periventricular hypothalamic nucleus & NS & & $p<0.0001$ & $\mathrm{C} v s \mathrm{~F}, p<0.01$ \\
\hline $\mathrm{Sch} / \mathrm{ox}$ & Suprachiasmatic nucleus & $p=0.0002$ & $\mathrm{C} v s \mathrm{~F}, p<0.01$ & NS & \\
\hline VMH & Ventromedial hypothalamic nucleus & NS & & $p=0.0049$ & $\mathrm{C} v s \mathrm{~F}, p<0.05$ \\
\hline \multicolumn{6}{|l|}{ Thalamus: } \\
\hline $\mathrm{AD}$ & Anterodorsal thalamic nucleus & NS & & $p<0.0001$ & $\mathrm{C} v s \mathrm{~F}, p<0.001$ \\
\hline $\mathrm{AV} / \mathrm{Rt}$ & Anteroventral thalamic nucleus & $p=0.0269$ & $\mathrm{C} v s \mathrm{~F}, p<0.01$ & $p=0.0003$ & $\mathrm{C} v s \mathrm{~F}, p<0.001$ \\
\hline $\mathrm{CL}$ & Centrolateral thalamic nucleus & NS & & $p<0.0001$ & $\mathrm{C} v s \mathrm{~F}, p<0.001$ \\
\hline $\mathrm{CM}$ & Central medial thalamic nucleus & NS & & $p<0.0001$ & $\mathrm{C} v s \mathrm{~F}, p<0.001$ \\
\hline G & Gelatinosus thalamic nucleus & NS & & $p=0.0007$ & $\mathrm{C} v s \mathrm{~F}, p<0.01$ \\
\hline IMD & Intermediodorsal thalamic nucleus & NS & & $p<0.0001$ & $\begin{array}{r}\mathrm{C} v s \mathrm{~F}, p<0.001 \\
(\text { Continued })\end{array}$ \\
\hline
\end{tabular}


Table 1. Continued

\begin{tabular}{|c|c|c|c|c|c|}
\hline \multirow{2}{*}{$\begin{array}{l}\text { Brain regions } \\
\text { and subregions }\end{array}$} & \multirow{2}{*}{$\begin{array}{l}\text { Labels for brain subregions } \\
\text { (also apply to Figures } 1,2,4)\end{array}$} & \multicolumn{2}{|c|}{$\begin{array}{l}\text { Neuronal cell death } \\
\text { (FJB staining) }\end{array}$} & \multicolumn{2}{|c|}{$\begin{array}{l}\text { Neuronal activation } \\
\text { (Fos expression) }\end{array}$} \\
\hline & & K-W ANOVA & Dunn's test & K-W ANOVA & Dunn's test \\
\hline $\mathrm{PC}$ & Paracentral thalamic nucleus & $p=0.0014$ & $\mathrm{C} v s \mathrm{~F}, \mathrm{NS}$ & $p=0.0001$ & $\mathrm{C} v s \mathrm{~F}, p<0.001$ \\
\hline Po & Posterior thalamic nuclear group & $p<0.0001$ & $\mathrm{C} v s \mathrm{~F}, p<0.001$ & & \\
\hline PT & Paratenial thalamic nucleus & NS & & $p<0.0001$ & $\mathrm{C} v s \mathrm{~F}, p<0.001$ \\
\hline RH & Rhomboid thalamic nucleus & NS & & $p=0.0095$ & $\mathrm{C} v s \mathrm{~F}, p<0.01$ \\
\hline VL & Ventrolateral thalamic nucleus & $p=0.0037$ & $\mathrm{C} v s \mathrm{~F}, \mathrm{NS}$ & NS & \\
\hline
\end{tabular}

Summed cell counts for Fos or FJB-positive cells were compared between groups; Pictograms in Figure 4 display group differences in cell counts obtained from anterior, intermediate and posterior cryosections.

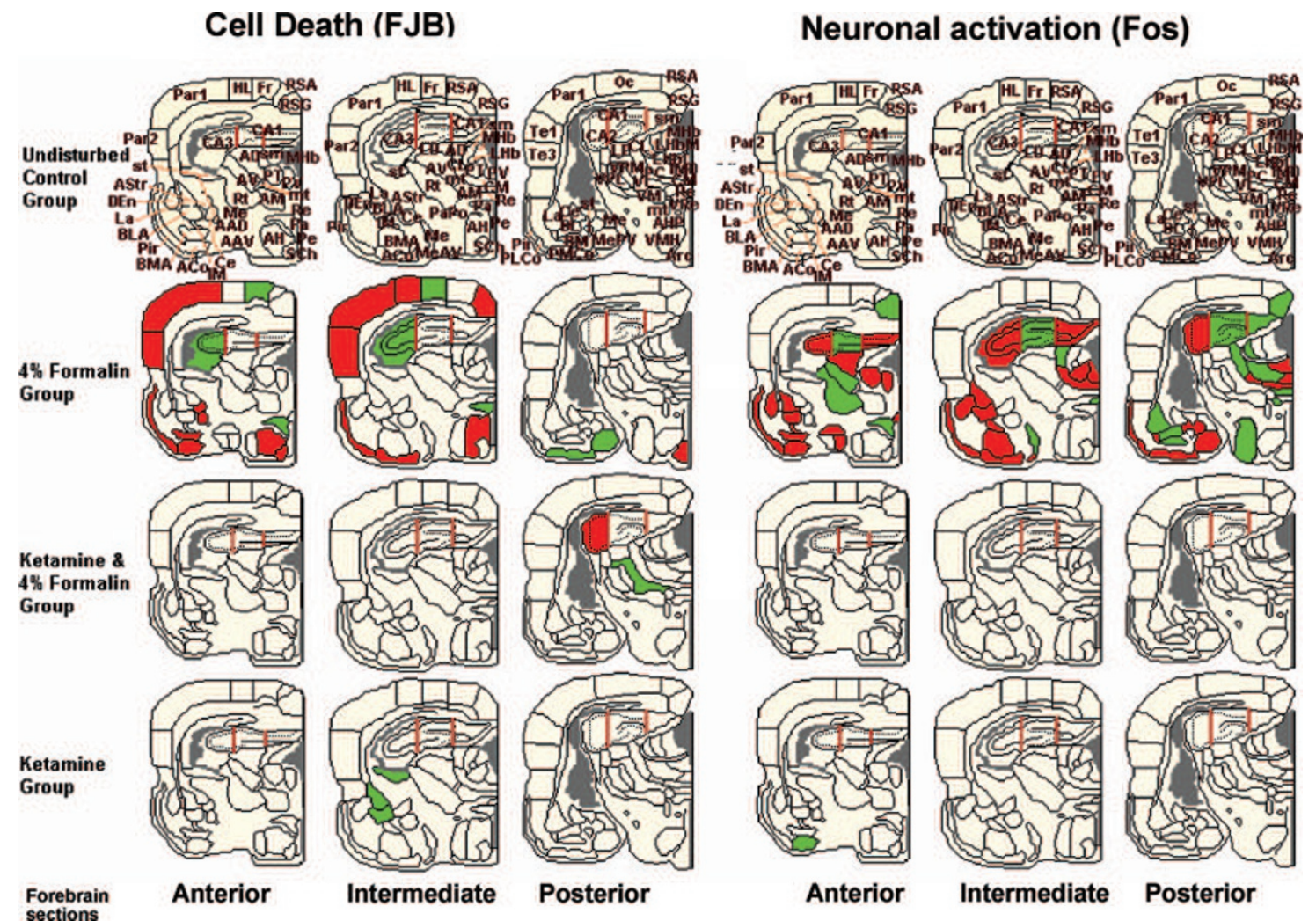

Figure 4. Pictograms of cellular differences from the control group, noted in anterior, intermediate, and posterior sections of the forebrain (red $p<0.001$, green $p<0.01$ ). Differences between individual nuclei and cortical areas from the $\mathrm{C}$ group (labels in Table 1), show widespread increases in cell death and decreases in Fos expression in the Formalin (F) group, which were blocked in the KF group. Significantly reduced Fos expression occurred in the F group compared with $\mathrm{C}$ group in the thalamic, hypothalamic, amygdalar, and hippocampal regions, but not in cortical areas. No differences occurred in the Fos expression between the $\mathrm{C}$ group and $\mathrm{K}$ or $\mathrm{KF}$ groups, except for reduced Fos expression in anterior basomedial amygdalar nucleus in the $\mathrm{K}$ group $(p<0.01)$.

accentuated cell death in the $\mathrm{F}$ group, associated with reduced neuronal Fos expression. Glial activation, expression of proinflammatory cytokines, prolonged pain facilitation and hyperalgesia (36-38) are likely to produce prolonged neuronal hyperexcitability in cortical and subcortical areas. Cell death in these areas may occur from such prolonged excitation, reduced glutamate re-uptake at NMDA synapses, or direct excitotoxicity via microglial activation (39). We speculate that reduced cell death in the ketamine-treated rats resulted from its analgesic effects, blockade of long-term pain facilitation (40), or its anti-inflammatory effects inhibiting neutrophil activation and migration (41), although direct evidence for these mechanisms are lacking (42). Ketamine shows similar neuroprotective effects in experimental models of brain injury (43), infection (44), seizures (45), or heart-lung bypass (46).

Since infant rats were killed at $18-20 \mathrm{~h}$ after the last formalin injection, the reduced activation of neuronal Fos may reflect a diminished viability of cortical, hippocampal, and other neurons, coupled with reduced activation via environmental stimuli. In contrast, neuronal activation in the hypothalamus was relatively spared, perhaps mediating stress responses and maintaining bodily functions during this period of repeated stress (47). 
A
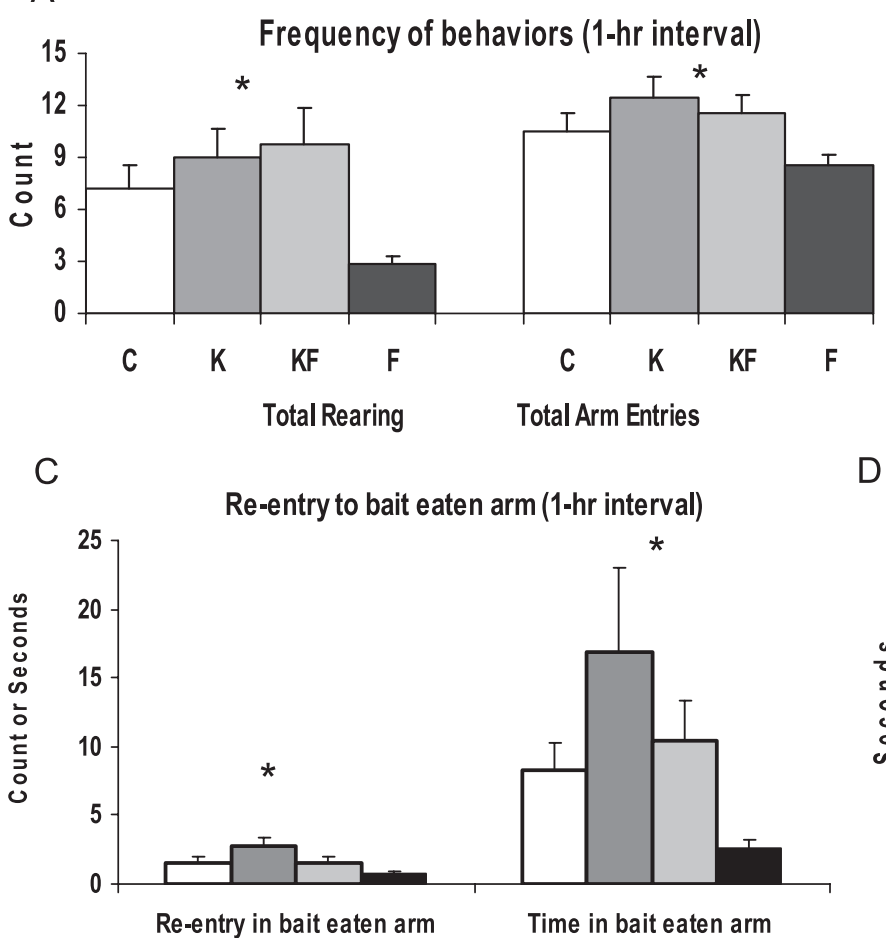

D
B
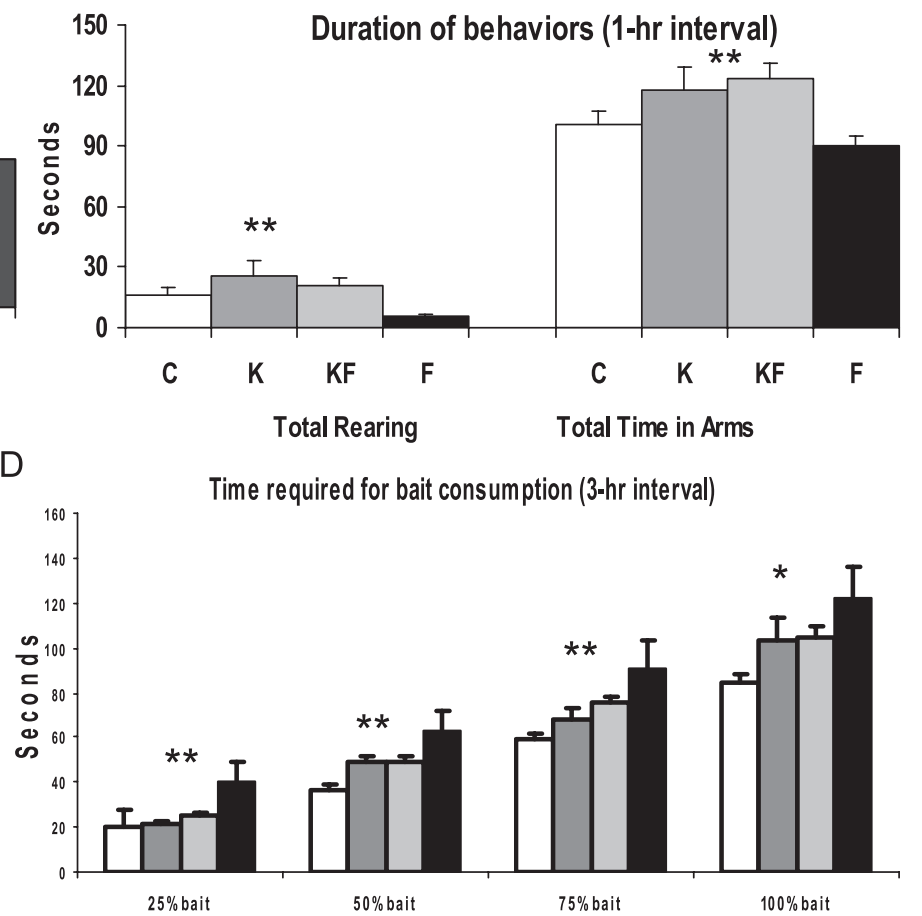

Figure 5. Visual-spatial learning in adult rats was examined in the radial 8 -arm maze test $(\mathrm{C}=27, \mathrm{~K}=24, \mathrm{KF}=21, \mathrm{~F}=20)$, with inter-exposure intervals of $1 \mathrm{~h}$ (P63) and $3 \mathrm{~h}$ (P64). (A) and (B): After the 1-h interval, the frequency and duration of rearing, and the frequency and duration of exploratory behaviors were reduced in the $\mathrm{F}$ group. $(C)$ The $\mathrm{F}$ group also had a lower frequency of re-entry and time spent in the bait eaten arms. Greater exploratory and rearing behaviors occurred in the ketamine-treated groups (K, KF) implying greater acquisition of visual-spatial cues. (D) Following a 3-h interval, the F group required longer durations for bait consumption, suggestive of impaired learning in a delayed nonmatch to sample (DNMS) paradigm. $* p<0.05 ; * *<0.01$.

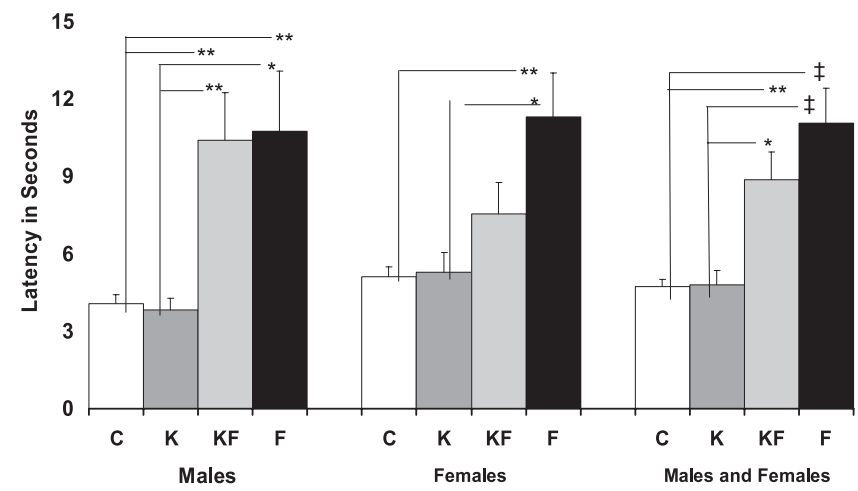

Figure 6. Hot plate latencies were measured at P74, after adult rats had recovered from diet restriction. Responses to thermal pain were dampened in formalin-treated animals, with longer latencies in the $\mathrm{F}$ and $\mathrm{KF}$ groups for males (ANOVA, $p<0.001$ ), for females $(p<0.003$ ), and combined groups $(p<0.001)$. Ketamine treatment in neonatal rats appears to ameliorate these long-term changes in adult females, but not in males. * $p<0.05 ; * * p<0.01$; $\ddagger p<0.001$.

Ketamine is widely used for producing anesthesia in human neonates, although high doses of ketamine trigger widespread neurodegeneration in newborn rats (16). The therapeutic relevance of these findings remains unclear because these studies used repeated, high-dose ketamine in the absence of surgical stimulation, which does not reflect clinical practice (48-50). Similar concerns plague the clinical applicability of in vitro data from a primate model (51). In contrast, the cell death induced by repetitive pain is ameliorated, at least partially, by clinically relevant doses of ketamine.
Rat pups from all experimental groups were raised to adulthood to assess thermal pain thresholds and visual-spatial learning. Exposure to neonatal inflammatory pain raised subsequent thermal pain thresholds, reminiscent of pain behaviors reported by parents of ex-preterm children $(1,52)$. Strikingly, morphine treatment in neonatal rats ameliorated the long-term effects of inflammatory pain in adult males but not in females (20); whereas ketamine ameliorates these long-term effects in female rats, but not in males.

The DNMS paradigm specifically tests the integrity of hippocampal function, whereas the frequency of rearing and exploratory behaviors denotes attentional processes $(18,19)$. Attentional processing, learning, and memory may be impaired following premature birth (26). Hippocampal cell death in was highest in the $\mathrm{F}$ group, less in the $\mathrm{C}$ and $\mathrm{KF}$ groups, and lowest in the $\mathrm{K}$ group, possibly associated with changes in perception and discrimination of spatial or ordinal cues (53). Areas showing enhanced cell loss in these experiments may overlap with some of the brain regions showing volumetric reductions in prematurely born children (54).

Reduction in pain-induced cell death by clinical doses of ketamine analgesia should prompt studies investigating its safety and efficacy in the preterm neonates exposed to prolonged pain.

Acknowledgments. The authors thank Yasmin Golzar, Robin Morris, Stephen Baker, Matthew S. Saltz, Brandy Tharp, and Brandon Mack for providing technical assistance. 


\section{REFERENCES}

1. Whitfield MF, Grunau RE 2000 Behavior, pain perception, and the extremely low-birth weight survivor. Clin Perinatol 27:363-379

2. Botting N, Powls A, Cooke RW, Marlow N 1997 Attention deficit hyperactivity disorders and other psychiatric outcomes in very low birthweight children at 12 years. J Child Psychol Psychiatry 38:931-941

3. Anand KJS, Runeson B, Jacobson B 2004 Gastric suction at birth associated with long-term risk for functional intestinal disorders in later life. J Pediatr 144:449-454

4. Peters JW, Schouw R, Anand KJS, van Dijk M, Duivenvoorden HJ, Tibboel D 2005 Does neonatal surgery lead to increased pain sensitivity in later childhood? Pain 114:444-454

5. Coplan JD, Andrews MW, Rosenblum LA, Owens MJ, Friedman S, Gorman JM, Nemeroff CB 1996 Persistent elevations of cerebrospinal fluid concentrations of corticotropin-releasing factor in adult nonhuman primates exposed to early-life stressors: implications for the pathophysiology of mood and anxiety disorders. Proc Nat Acad Sci U S A 93:1619-1623

6. Jacobson B, Bygdeman M 1998 Obstetric care and proneness of offspring to suicides as adults: case-control study. Brit Med J 317:1346-1349

7. Salk L, Lipsitt LP, Sturner WQ, Reilly BM, Levat RH 1985 Relationship of maternal and perinatal conditions to eventual adolescent suicide. Lancet 1:624-627

8. Simons SHP, van Dijk M, Anand KJS, Roofthooft D, van Lingen RA, Tibboel D 2003 Do we still hurt newborn babies? A prospective study of procedural pain and analgesia in neonates. Arch Pediatr Adolesc Med 157:1058-1064

9. Chahal H, D'Souza SW, Barson AJ, Slater P 1998 Modulation by magnesium of $\mathrm{N}$-methyl-D-aspartate receptors in developing human brain. Arch Dis Child Fetal Neonatal Ed 78:F116-F120

10. Rabinowicz T, de Courten-Myers GM, Petetot JM, Xi G, de los Reyes E 1996 Human cortex development: estimates of neuronal numbers indicate major loss late during gestation. J Neuropathol Exp Neurol 55:320-328

11. Anand KJS, Coskun V, Thrivikraman KV, Nemeroff CB, Plotsky PM 1999 Longterm behavioral effects of repetitive pain in neonatal rat pups. Physiol Behav 66:627-637

12. Sternberg WF, Ridgway CG 2003 Effects of gestational stress and neonatal handling on pain, analgesia, and stress behavior of adult mice. Physiol Behav 78:375-383

13. Grunau RE, Weinberg J, Whitfield MF 2004 Neonatal procedural pain and preterm infant cortisol response to novelty at 8 months. Pediatrics 114:e77-e84

14. Jevtovic-Todorovic V, Hartman RE, Izumi Y, Benshoff ND, Dikranian K, Zorumski CF, Olney JW, Wozniak DF 2003 Early exposure to common anesthetic agents causes widespread neurodegeneration in the developing rat brain and persistent learning deficits. J Neurosci 23:876-882

15. Morgane PJ, Mokler DJ, Galler JR 2002 Effects of prenatal protein malnutrition on the hippocampal formation. Neurosci Biobehav Rev 26:471-483

16. Ikonomidou C, Bosch F, Miksa M, Bittigau P, Vockler J, Dikranian K, Tenkova TI, Stefovska V, Turski L, Olney JW 1999 Blockade of NMDA receptor and apoptotic neurodegeneration in the developing brain. Science 283:70-74

17. Schmued LC, Hopkins KJ 2000 Fluoro-Jade B: a high affinity fluorescent marker for the localization of neuronal degeneration. Brain Res 874:123-130

18. Walsh TJ, Chrobak JJ 1987 The use of the radial arm maze in neurotoxicology. Physiol Behav 40:799-803

19. Boast CA, Walsh TJ, Bartolomeo AC 2001 The delayed non-match-to-sample radial arm maze task: application to models of Alzheimer's disease. In: Buccafusco JJ (ed) Methods of Behavior Analysis in Neuroscience. CRC Press LLC, Boca Raton, FL, pp 167-188

20. Bhutta AT, Rovnaghi CR, Simpson PM, Gosset JM, Scalzo FM, Anand KJS 2001 Interactions of inflammatory pain and morphine treatment in infant rats: long-term behavioral effects. Physiol Behav 73:51-58

21. Robertson SJ, Burnashev N, Edwards FA 1999 Ca2 + permeability and kinetics of glutamate receptors in rat medial habenula neurones: implications for purinergic transmission in this nucleus. J Physiol 518:539-549

22. Boyle EM, Freer Y, Wong CM, McIntosh N, Anand KJS 2006 Assessment of persistent pain or distress and adequacy of analgesia in preterm ventilated infants. Pain 124:87-91

23. Bartocci M, Bergqvist LL, Lagercrantz H, Anand KJS 2006 Pain activates cortical areas in the preterm newborn brain. Pain 122:109-117

24. Peterson BS, Anderson AW, Ehrenkranz R, Staib LH, Tageldin M, Colson E, Gore JC, Duncan CC, Makuch R, Ment LR 2003 Regional brain volumes and their later neurodevelopmental correlates in term and preterm infants. Pediatrics 111:939-948

25. McCormick MC, Gortmaker SL, Sobol AM 1990 Very low birth weight children: behavior problems and school difficulty in a national sample. J Pediatr 117:687-693

26. Bhutta AT, Cleves MA, Casey PH, Cradock MM, Anand KJS 2002 Cognitive and behavioral outcomes of school-aged children who were born preterm: a metaanalysis. JAMA 288:728-737

27. McCormick MC, Brooks-Gunn J, Workman-Daniels K, Turner J, Peckham GJ 1992 The health and developmental status of very low-birth-weight children at school age. JAMA 267:2204-2208
28. Slonim AD, Patel KM, Ruttimann UE, Pollack MM 2000 The impact of prematurity: a perspective of pediatric intensive care units. Crit Care Med 28:848-853

29. Grunau RE, Whitfield MF, Petrie J 1998 Children's judgements about pain at age $8-10$ years: do extremely low birthweight $(<$ or $=1000 \mathrm{~g})$ children differ from full birthweight peers? J Child Psychol Psychiatry 39:587-594

30. Breslau N, Chilcoat HD, Johnson EO, Andreski P, Lucia VC 2000 Neurologic soft signs and low birthweight: their association and neuropsychiatric implications. Biol Psychiatry 47:71-79

31. Abbott FV, Guy ER 1995 Effects of morphine, pentobarbital and amphetamine on formalin-induced behaviours in infant rats: sedation versus specific suppression of pain. Pain 62:303-312

32. Johnston CC, Walker CD 2003 The effects of exposure to repeated minor pain during the neonatal period on formalin pain behaviour and thermal withdrawal latencies. Pain Res Manag 8:213-217

33. Barr GA 1998 Maturation of the biphasic behavioral and heart rate response in the formalin test. Pharmacol Biochem Behav 60:329-335

34. Ruda MA, Ling Q-D, Hohmann AG, Peng YB, Tachibana T 2000 Altered nociceptive neuronal circuits after neonatal peripheral inflammation. Science 289:628-631

35. Spreafico R, Frassoni C, Arcelli P, Selvaggio M, De Biasi S 1995 In situ labeling of apoptotic cell death in the cerebral cortex and thalamus of rats during development. J Comp Neurol 363:281-295

36. Fu KY, Light AR, Maixner W 2000 Relationship between nociceptor activity, peripheral edema, spinal microglial activation and long-term hyperalgesia induced by formalin. Neuroscience 101:1127-1135

37. Wu Y, Willcockson HH, Maixner W, Light AR 2004 Suramin inhibits spinal cord microglia activation and long-term hyperalgesia induced by formalin injection. J Pain 5:48-55

38. Ledeboer A, Sloane EM, Milligan ED, Frank MG, Mahony JH, Maier SF, Watkin LR 2005 Minocycline attenuates mechanical allodynia and proinflammatory cytokine expression in rat models of pain facilitation. Pain 115:71-83

39. Epstein LG, Gelbard HA 1999 HIV-1-induced neuronal injury in the developing brain. J Leukoc Biol 65:453-457

40. Klein T, Magerl W, Nickel U, Hopf HC, Sandkuhler J, Treede RD 2007 Effects of the NMDA-receptor antagonist ketamine on perceptual correlates of long-term potentiation within the nociceptive system. Neuropharmacology 52:655-661

41. Lewis E, Rogachev B, Shaked G, Douvdevani A 2001 The in vitro effects of ketamine at large concentrations can be attributed to a nonspecific cytostatic effect. Anesth Analg 92:927-929

42. Anand KJS, Scalzo FM 2000 Can adverse neonatal experiences alter brain development and subsequent behavior? Biol Neonate 77:69-82

43. Smith DH, Koichi O, Gennarelli TA, McIntosh TK 1993 Magnesium and ketamine attenuate cognitive dysfunction following experimental brain injury. Neurosci Lett $157: 211-214$

44. Takenaka I, Ogata M, Koga K, Matsumoto T, Shigematsu A 1994 Ketamine suppresses endotoxin-induced tumor necrosis factor alpha production in mice. Anesthesiology 80:402-408

45. Trommer BL, Pasternak JF 1990 NMDA receptor antagonists inhibit kindling epileptogenesis and seizure expression in developing rats. Brain Res Dev Brain Res 53:248-252

46. Roytblat L, Talmor D, Rachinsky M, Greemberg L, Pekar A, Appelbaum A, Gurman GM, Shapira Y, Duvdenani A 1998 Ketamine attenuates the interleukin-6 response after cardiopulmonary bypass. Anesth Analg 87:266-271

47. Lariviere WR, Melzack R 2000 The role of corticotropin-releasing factor in pain and analgesia. Pain 84:1-12

48. Hayashi H, Dikkes P, Soriano SG 2002 Repeated administration of ketamine may lead to neuronal degeneration in the developing rat brain. Paediatr Anaesth 12:770774

49. Anand KJS, Soriano SG 2004 Anesthetic agents and the immature brain: are these toxic or therapeutic agents? Anesthesiology 101:527-530

50. Scallet AC, Schmued LC, Slikker W Jr, Grunberg N, Faustino PJ, Davis H, Lester D, Pine PS, Sistare F, Hanig JP 2004 Developmental neurotoxicity of ketamine: morphometric confirmation, exposure parameters, and multiple fluorescent labeling of apoptotic neurons. Toxicol Sci 81:364-370

51. Wang C, Sadovova N, Hotchkiss C, Fu X, Scallet AC, Patterson T, Hanig J, Paule MG, Slikker W Jr 2006 Blockade of N-Methyl-D-Aspartate receptors by ketamine produces loss of postnatal day 3 monkey frontal cortical neurons in culture. Toxicol Sci 91:192-201.

52. Grunau RV, Whitfield MF, Petrie JH 1994 Pain sensitivity and temperament in extremely low-birth-weight premature toddlers and preterm and full-term controls. Pain 58:341-346

53. Gilbert PE, Kesner RP 2002 Role of the rodent hippocampus in paired-associate learning involving associations between a stimulus and a spatial location. Behav Neurosci 116:63-71

54. Peterson BS, Vohr B, Staib LH, Cannistraci CJ, Dolberg A, Schneider KC, Katz KH, Westerveld M, Sparrow S, Anderson AW, Duncan CC, Makuch RW, Gore JC, Ment LR 2000 Regional brain volume abnormalities and long-term cognitive outcome in preterm infants. JAMA 284:1939-1947 